
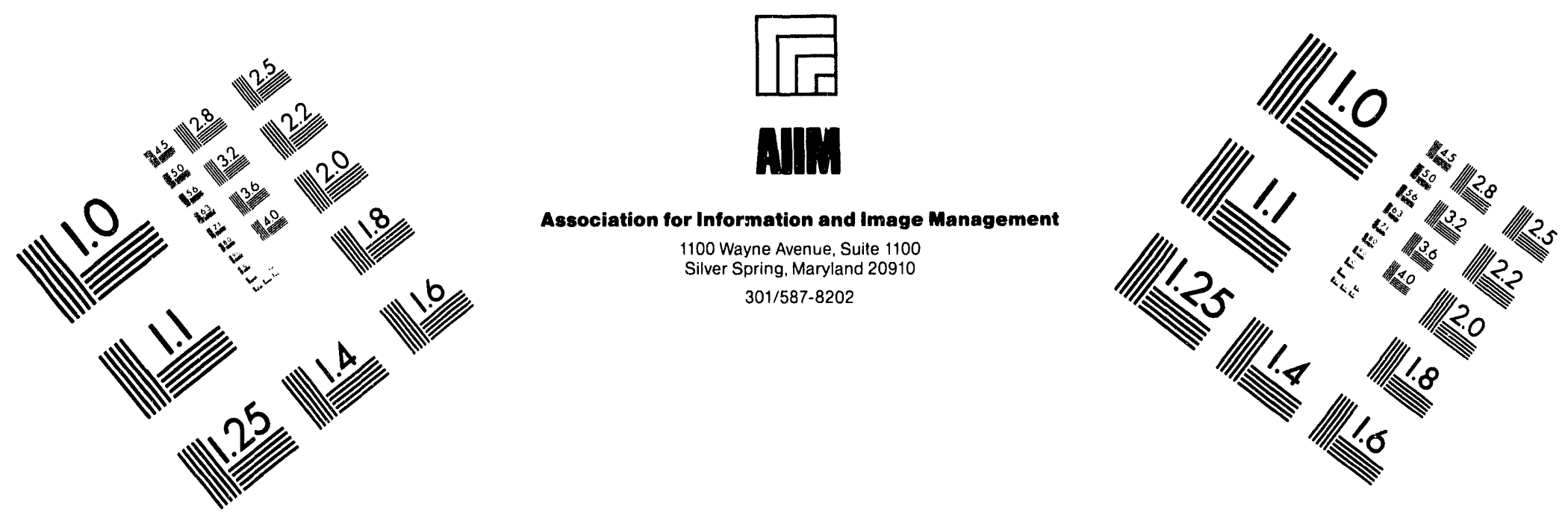

\title{
Centimeter
}

$\begin{array}{llllllllllllllll}1 & 2 & 3 & 4 & 5 & 6 & 7 & 8 & 9 & 10 & 11 & 12 & 13 & 14 & 15 & \mathrm{~mm}\end{array}$

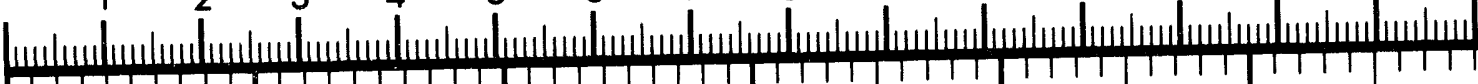

TITाTा

Inches
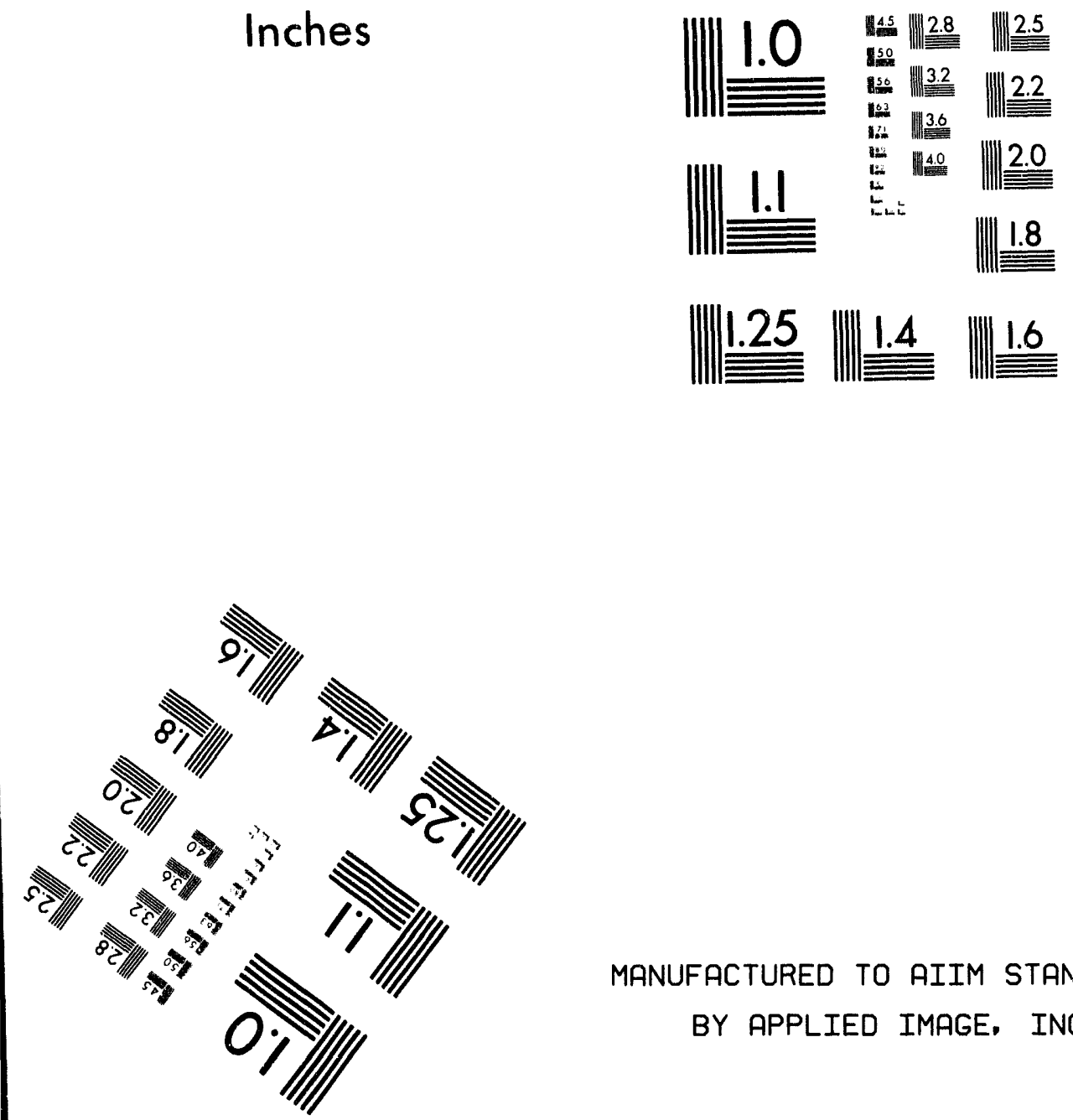

MANUFACTURED TO AIIM STANDARDS

BY APPLIED IMAGE, INC.

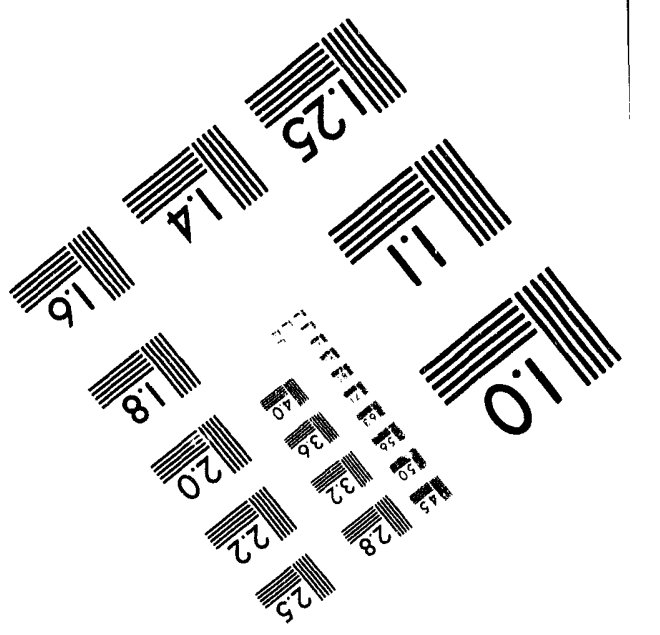



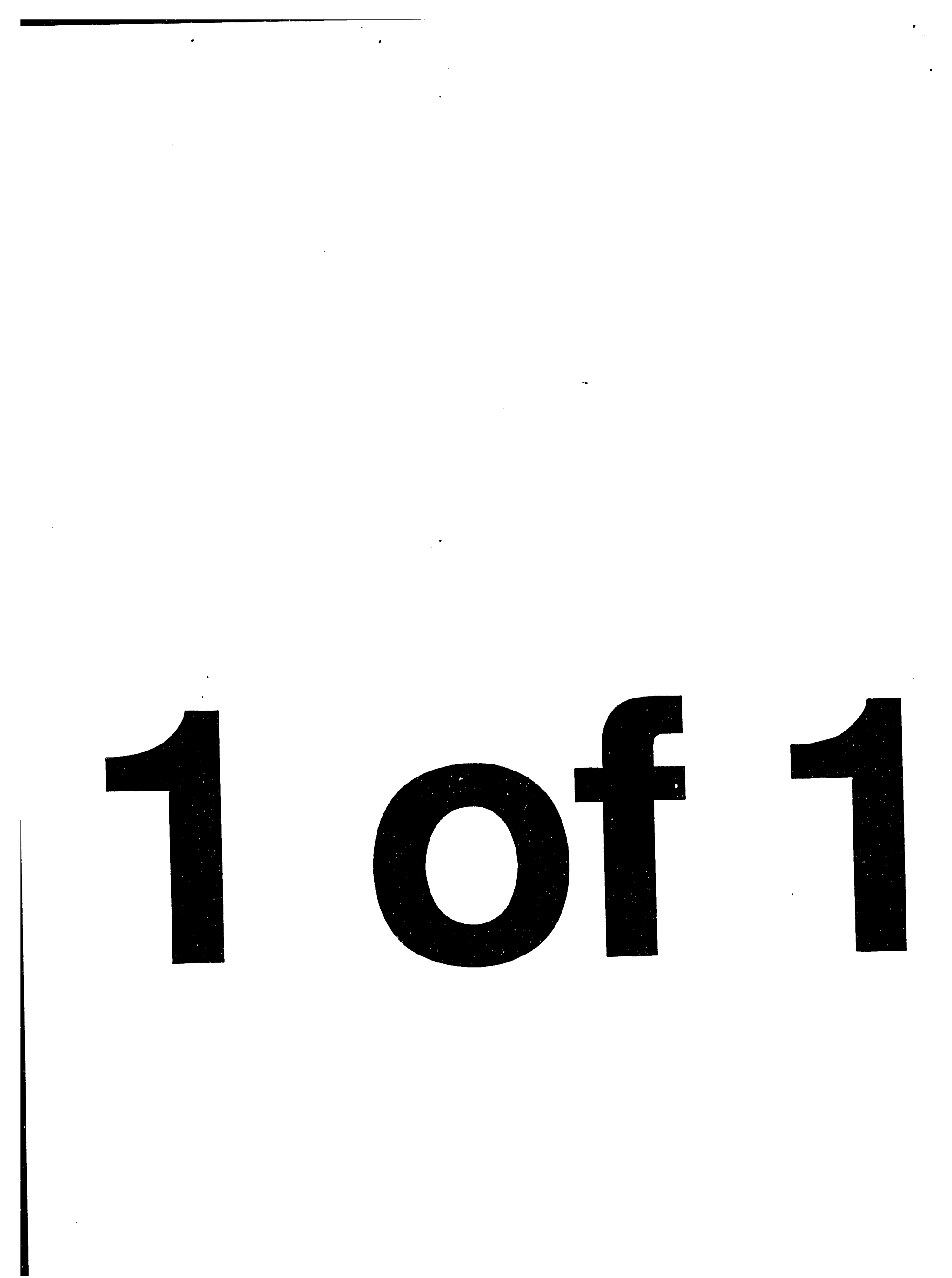
WSRC-RP-94-197，Rev. O

\section{PROGRAM PLAN: DWPF/HLWDP STIRRED MELTER PROGRAM PLAN (U)}

M. E. Smith

Defense Waste Processing Technology

Savannah River Technology Center

Westinghouse Savannah River Company

Savannah River Site

Aiken, SC 29808

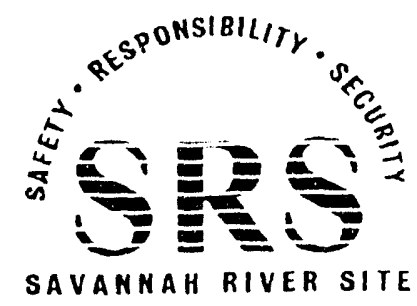

Prepared for the U. S. Department of Energy under contract No. DE-AC09-89SR18035 
This report was prepared by Westinghouse Savannah River Company (WSRC) for the United States Department of Energy under Contract No. DEAC09-89SR 18035 and is an account of work performed under that contract. Neither the United States Department of Energy, nor WSRC, nor any of their employees makes any warranty, expressed or implied, or assumes any legal liability or responsibility for the accuracy, completeness, or usefulness, of any information, apparatus, or product or process disclosed herein or represents that its use will not infringe privately owned rights. Reference herein to any specific commerical product, process, or service by trademark, name, manufacturer or otherwise does not necessarily constitute or imply endorsement, recommendation, or favoring of same by WSRC or by the United States Government or any agency thereof. The views and opinions of the authors expressed herein do not necessarily state or reflect those of the United States Government or any agency thereof. 
WSRC-RP-94-197, Rev. 0

Keywords: DWPF, Glass,

Vitrification, Stirred Melter, Melter

Retention: 15 Years

\section{PROGRAM PLAN: DWPF/HLWDP STIRRED MELTER PROGRAM PLAN (U)}

M. E. Smith

Publication Date: February 28, 1994

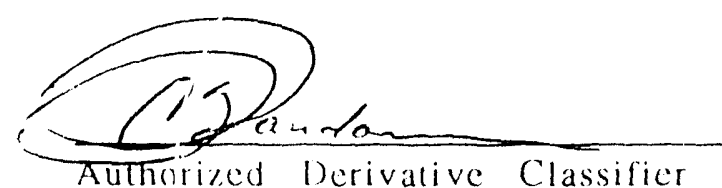

Westinghouse Savannah River Company Savannah River Site Aiken, SC 29808

Prepared for the U. S. Department of Energy under contract No. DE-ACO9-89SR180135
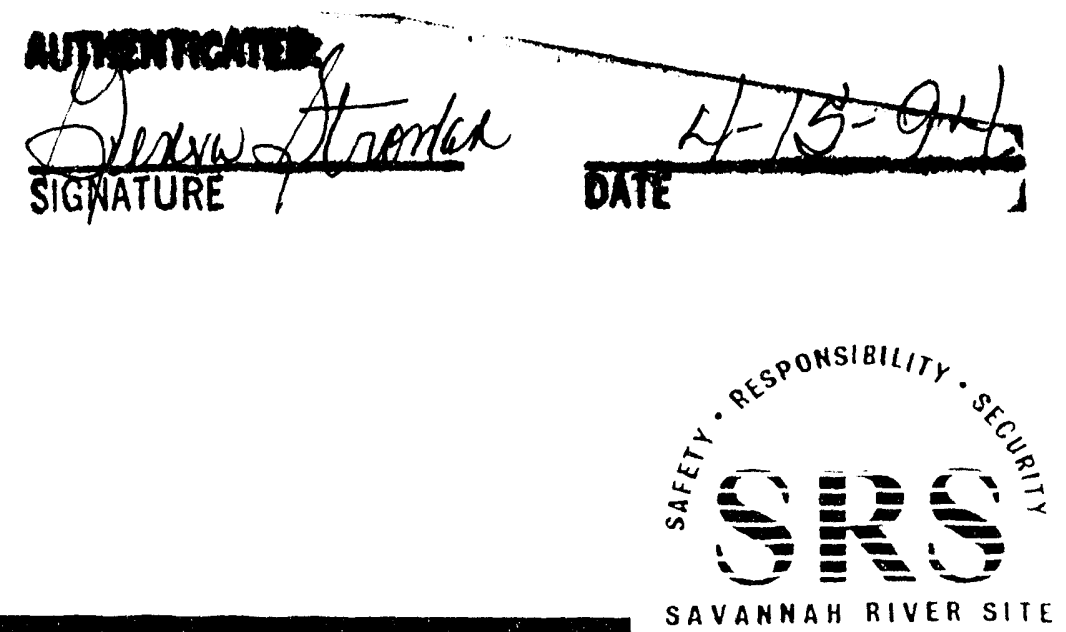


\section{APPROVAL PAGE}

Approved by:
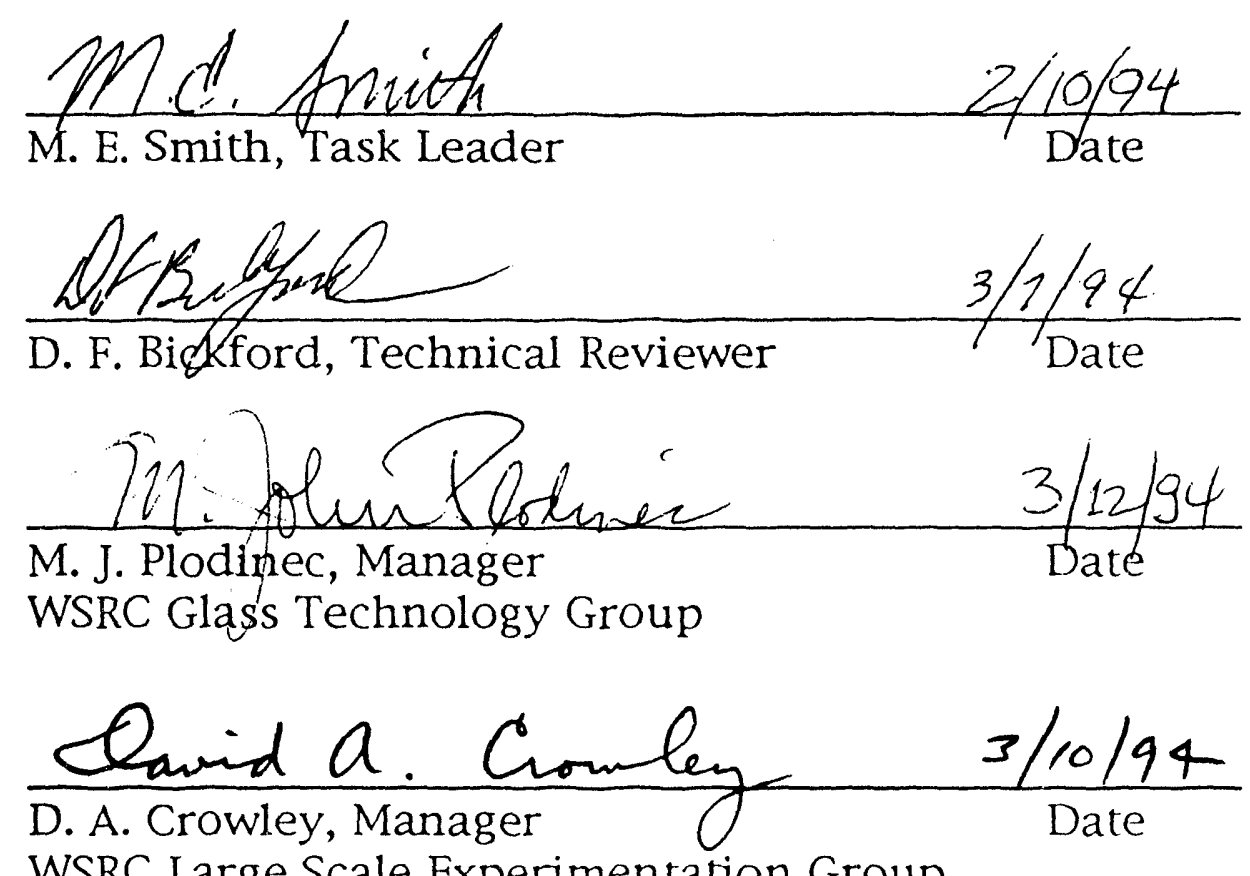

WSRC Large Scale Experimentation Group

\section{Ew bloctzohe}

E. W. Holtzscheiter, Manager

WSRC Defense Waste Processing Technology
$3 / 18 / 94$

Date

\begin{tabular}{|c|c|}
\hline 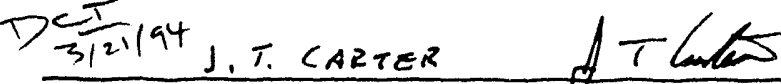 & $3 / 25 / 94$ \\
\hline $\begin{array}{l}\text { F.A.Gentucci, Managef } \\
\text { WSRC DWPF Process, Engineering } \\
\text { cocnuleavT }\end{array}$ & Date \\
\hline ExJeber & $3 / 29 / 94$ \\
\hline $\begin{array}{l}\text { E. T. Weber, Manager } \\
\text { WHC HLWDP Technology }\end{array}$ & Date \\
\hline
\end{tabular}




\section{Introduction and Summary}

Slurry Fed Melters (SFM) have been developed in the United States, Europe and Japan for the conversion of High Level radioactive wa:te (HLW) to borosilicate glass for permanent disposal $\{1-8\}$. Laboratory and pilot scale operations have been conducted to develop equipment, glass compositions and control methods. The melters developed fall into four categories: batch melters, continuous pot melters, Joule-heated ceramiclined melters, and stirred melters. The newest design, the stirred melter $\{1,8\}$, combines the high production rates and high glass quality features of the Joule-heated melters with the low-cost, compact, simple maintenance features of the pot melters. However, further engineering design and demonstrations are needed to operate the stirred melter on a large scale.

This document outlines the program which develops a full scale stirred melter for the DWPF (240 pph), and provides a basis which will allow further scale-up of the technology for use in the Hanford High Level Waste Disposal Program (HLWDP) for up to four times the reference capacity. The Full Scale DWPF Stirred Melter will be installed in the IDMS facility at TNX. Tie-ins into the existing IDMS feed delivery and off-gas systems will be made to reduce project costs.

This is a joint DWPF/HLWDP development program. This program plan will be amended as required to support future HLWDP Stirred Melter development plan testing requirements. 


\section{Program Plan}

\section{TNX Stirred Melter Design Features}

The design features incorporated into the TNX stirred melter are based on the premise that 1) the glass making process and particularly any glass contact mechanisms will be demonstrated and 2) remoteability features requiring only design and no experimentation to verify the design will not be demonstrated.

The TNX stirred melter has the following design features:

- the design melt rate is $240 \mathrm{pph}$,

- Inconel $690^{\mathrm{rm}}$ is the reference material of construction for all glass contact areas,

- the distance between the main pot pour valve and the superheater drain valve is prototypic of the existing DWPF Melter design, (the relative elevation difference is not prototypic),

- the superheater is designed to provide a glass residence time of 4 hours at $1150^{\circ} \mathrm{C}$ to meet the glass durability requirements,

- the melter cooling system is designed to provide melter surface temperatures less than $50^{\circ} \mathrm{C}$ to match the existing DWPF Melter design criteria,

- the agitator shaft changer for remote removal of the agitator will be demonstrated, and

- the melter is designed to facilitate maintenance of either the primary melter or superheater; the superheater can be displaced 34 inches (while at operating temperatures) to allow the primary melter to be taken out of service or it can be taken out of service independently. This will allow for remote replacement feasibility tests to be done on both the primary melter and the superheater. Due to cost constraints, the melter is not designed for easy/remote removal of the melter pot. This would be a requirement for a stirred melter for the DWPF or the HLWDP. 


\section{Test Program Objectives}

The overall objective for the program is to develop a full scale stirred melter for the DWPF (240 pph), and provide a basis which will allow further scale-up of the technology for use in the Hanford HLWDP for up to four times the reference capacity. The program will use DWPF Design Basis, DWPF High Viscosity, DWPF Low Viscosity, DWPF Batch 2, DWPF Batch 3, HLWDP NCAW, HLWDP DST-SST Nominal Blend, and HLWDP DSTSST Blend feed materials.

The HLWDP will prepare an HLWDP Stirred Melter Technology Development Plan which will identify specific HLWDP related test objectives. The primary emphasis of the HLWDP test objectives will be to provide data and information necessary to resolve stirred melter concept feasibility, scale up to higher capacities, and feed composition issues.

During the processing of all feed types the following objectives apply:

- glass durability will be determined using the DWPF PCT and will be compared to the Waste Acceptance limits,

- other glass properties will be determined as required for each test,

- melter production rate will be determined,

- normal operating parameters (current, power, voltage, etc.) will be determined,

- combustion efficiency for organic constituents will be determined, and

- glass pouring control (superheater pour valve) will be evaluated. :

Selected specific tests will address the following objectives:

- The drain valve operation for both the superheater and the primary melter will be tested,

- agitator speed effects on melt rate and entrainment will be tested,

- agitator elevation effects on melt rate and entrainment will be tested, 
- new agitator designs will be tested as they become available,

- off gas dynamics (especially surges) will be investigated, and

- slurry feed distribution will be varied (melter currently has only a single feed tube) to determine the effect on melt rate and entrainment.

The following overall objectives apply to the verification of equipment design over the life of the project:

- agitator and tank life will be estimated based on non-destructive and destructive tests,

- primary melter tank replacement will be dernonstrated,

- superheater replacement will be demonstrated,

- agitator replacement will be demonstrated,

- life of melter top head components and melter wall thermocouples will be determined or estimated based on operating experience,

- agitator seal design will be demonstrated, and modified as required,

- replaceable off gas baffles will be tested to determine if the film cooler is required.

The following supporting studies are also required to maximize the benefit from the stirred melter:

- the Inconel $690^{\mathrm{TM}}$ creep studies begun at SRS in FY 92 will be completed,

- alternative materials of construction (especially for the agitator) studies will be continued, and

- small scale stirred melter studies both at the Vitrification Center at Clemson University (one-quarter foot square melter) and at Associated Technical Consultants (ATC) (one foot square melter) will be continued to fully develop the required scale-up 
parameters for the HLWDP. These scale-up parameters include melt surface area and melt volume.

\section{Program Requirements}

Due to the importance of this program, any activities performed to meet the above objectives is designated as a task activity as defined in WSRC Procedure Manual 1Q As such all activities will be controlled in accordance with implementing procedure 2-3 of WSRC Procedure Manual $1 \mathrm{Q} 43$.

The Task Leader for this activity is M. E. Smith of the Large Scale Experimentation Group. The specific detailed objectives and how each objective will be achieved will be documented in a Technical Task Plan (or Plans). The detailed specific objectives are to be mutually agreed upon by the Task Leader, the WSRC Large Scale Experimentation Group Manager, the DWPF Process Cognizant Engineering Manager, the WHC HLWDP Technology Group Manager, and the PNL HLWDP Technology Manager. The Task Plan will be prepared by the Task Leader and approved by the above individuals as well as any mutually agreed upon technical reviewers. The Task Plan will include a schedule for test activities.

A Task QA Plan will also be prepared by the Task Leader in accordance with WSRC Manual 1243 and will be approved by the above individuals and the SRTC Cognizant Quality Function.

A records package will be prepared. This package will be sufficiently complete so that the experimentation could be independently performed by equally qualified personnel. The minimum content of the records package will be described in the Task Plan or Task QA Plan.

\section{Schedule}

The schedule for the installation of the TNX stirred melter is attached. The vendor order was let on September 15, 1993. The melter delivery date is September 1, 1994, and melter heat-up completion date is May 30, 1995.

WSRC, WHC, and PNL staff will participate in the vendor preliminary design review, and in the vendor fabrication drawing approval process. The same parties will also participate in the design reviews for the installation. 
The schedule for the testing activities will be a part of the Task Plan. The complete testing schedule is expected to take about three years. There will be approximately eight tests, with two in FY95, four in FY96, and two in FY97. Four of these tests will be specifically for the HLWDP (one in FY95, two in FY96, and one in FY97).

\section{Cost}

The total cost of the program will depend on the duration selected for each feed type and the total task duration. The anticipated spendout for this program for FY93, FY94, FY95, FY96, and FY97 is provided in Table 1. 
Table 1

Stirred Melter Cost Estimates ( $\$ K$ )

\section{Cost Elements}

Planning \& Coordination Define Product

Requirements for Hanforc

Glass Formulation

for Hanford waste

cold Bench Scale Testing

(Clemson Univ)

pilot Scale Design and

construction

Anticipated Capital

Equipment Needs

pilot Scale Test plans

('NSRC)

pilot scale Testing

(Hanford)

Total

FY93

Hanford/WSRC

FY94

$\$ 50 / \$ 50$

$\$ 100 / \$ 0$

$\$ 200 / 50$

$\$ 100 / \$ 0$

$\$ 0 / \$ 200 \$ 1,650 / \$ 2,250$

(a)

(a)

$\$ 100 / \$ 100$

$\$ 100 / \$ 100$
FY95

Hanford/WSRC $\$ 50 / \$ 50$

$\$ 300 / \$ 0$

$\$ 50 / \$ 0$

$\$ 0 / \$ 800$

(a)

$\$ 0 / \$ 1,200$

(b)

$\$ 100 / \$ 100$

(c)

$\$ 1,650 / \$ 0$

(d)
EY96

Hanford/WSRC

$\$ 50 / \$ 50$

$\$ 100 / \$ 0$

$\$ 4,650 / \$ 4,550$

$\$ 2,150 / \$ 3,450$

$\$ 0 / \$ 4,500$
$(\mathrm{c})$
$\$ 4,500 / \$ 0$

(d)

$\$ 0 / \$ 2,350$

$\$ 2,350 / \$ 0$

(d)

$\frac{\text { FY97 }}{\text { WSRC }}$

$\$ 50 / \$ 50$

$\$ 100 / \$ 300 \quad \$ 2,200 / \$ 2,400$

$\$ 2,400 / \$ 2,400$

Fuping provided is $\$ 2,600$ from DoE-HQ discretionary funding, a Capital Equipment Project $S-4845$. Funding provided installation/startup is as follows 1) design/ $\$ 1,650$ from Hanford, $\$ 650$ from DWPF. The project

Anticipated Capital Equipment needs for melter spare parts and improved off-gas system performance ( $\$ 500$ for spare melter pot).

c DWPF Pilot Scale Testing costs - FY95 (one 5 day run), FY96 (two 20 day runs),

(no noble metals)

FY97 (onè 20 day run)

d Hanford pilot scale Testing costs - FY95 (one 10 day run), Fy96 (two 20 day runs), (no noble metals) 


\section{REFERENCES - (INCLUDING APPENDIX)}

1. D. F. Bickford, "Advanced Radioactive Waste-Glass Melters", WSRCRP-89-1174, April 1990.

2. C. Chapman, J. M. Pope, S. M. Barnes,"Electric Melting of Nuclear Waste Glasses: State of the Art", J. NonCryst. S. 84 (1986) 226-240.

3. J. L. McElroy, W. J. Bjorklund, and W. F. Bonner,"Waste Vitrification: A Historical Perspective", The Treatment and Handling of Radioactive Wastes, Springer-Verlag (1982) 171-177.

4. C. C. Chapman,"Design Preferences for a Slurry-Fed Ceramic Melter,...", Proceedings 2nd International Symposium Ceramics in Nuclear Waste Management, 8 (American Ceramic Society 1983) 159.

5. J. P. Giraud, J. P. Conard, and P. M. Saverot,"Conceptual Design for Vitrification at West Valley,...", Proceedings 2nd International Symposium Ceramics in Nuclear Waste Management, 8 (American Ceramic Society 1983) 134.

6. J. D. Gutmann, Jr., "DWPF Melter Design Basis and Description", August 9, 1988.

7. R. S. Richards,"Rapid Glass Melting and Refining System", Advances in the Fusion of Glass (American Ceramic Society 1988) 50.1-50.11. See also U.S. Patent No. 3,988,138, October 26, 1976, "Method and Apparatus for Melting Glass-Making Materials".

8. R. S. Richards," Small High-Speed Glass Melter for Waste Vitrification", American Ceramic Society, Dallas TX, April 1990.

9. Y. S. Tang and J. S. Saling, Radioactive Waste Management Hemisphere Publications (1990).

10. D. F. Bickford, P. Hrma, and B. W. Bowan II,"Control of Radioactive Waste Glass Melters: Part II - Residence Time and Melt Rate Limitations", Journal American Ceramic Society (1990). 
11. D. F. Bickford, A. Applewhite-Ramsey, C. M. Jantzen, and K. G. Brown,"Control of Radioactive Waste Glass Melters: Part I Preliminary General Limits at Savannah River", Journal American Ceramic Society (1990).

12. D. F. Bickford, R. C. Propst, and M. J. Plodinec,"Control of Radioactive Waste Glass Melters Part III: Glass Electrical Stability", Advances in the Fusion of Glass (American Ceramic Society 1988) 19.1-19.17 . 


\section{APPENDIX - DISCUSSION OF DEVELOPMENT OF MELTER TECHNOLOGY}

\section{Available Melter Technology}

The Defense Waste Processing Facility (DWPF) being constructed at the U.S. Department of Energy's Savannah River Site has an anticipated operating life of over 16 years, using a remotely replaceable Joule-heated ceramic-lined melter with a minimum design life of 2 years. Similar equipment and facility development efforts for HLW disposal are underway at the West Valley Demonstration Project (WVDP), the Hanford High Level Waste Disposal Program (HLWDP), and in France, Belgium, the Federal Republic of Germany, and Japan. As part of this process, a number of melter systems of various capacities have been designed, constructed and operated. Most of these systems have been operated and maintained in non-radioactive and non-hazardous environments as part of equipment development and demonstrations. However, several large scale pilot and production units have been operated with either hazardous melter feeds, radioactive spikes, or HLW.

\section{Development of Melters for HLW Vitrification}

The majority of the current melter programs at SRS and Hanford are in support of the Joule-heated ceramic-lined melter design. The programs consider evolutionary design changes.

The first waste glass melters were designed for batch operations, and were a direct increase in scale from crucible tests. This approach was found unsuitable for HLW production facilities because of low melt rates caused by slow heat transfer from the external heaters through the canister into the reacting batch. Lack of uniform temperature and agitation made it difficult to homogenize the glass. Calcination of feed before introduction into the canister increased the melt rate but also increased the tendency for crystal formation in the glass and entrained waste in the calciner off-gas system. This method was finally eliminated for HLW based on the large number of melters, operating in parallel, needed to meet the production rates required to dispose of HLW inventories.

The second class of melters developed were continuous pot melters. In this type of melter, melt rate is increased by increasing the diameter of the pot, by direct heating of the pot by radio frequency induction heating, and by continuous feeding of raw materials. Glass homogeneity was improved by using gas bubblers to agitate the melt. The largest of this 
type of melter is the French AVH system which melts 55 pounds per hour. This is the processing rate limit per pot melter using dried feed. With slurry feeding the melter capacity limit would be about one half of this, or no more than 27 pounds per hour per melter. The melter design temperature is limited to about $1150^{\circ} \mathrm{C}$ by creep resistance of the Inconel ${ }^{\mathrm{TM}}$ alloy used for the pot. The use of this system was not practical in the DWPF because of the large number of parallel melters, calciners and off-gas scrubbing systems required. However, this class of melter is modular, with parts that are relatively easy to replace. An additional benefit of this approach is that only the failed components need be replaced, minimizing the amount of waste generated with melter changeout, and maximizing the useful life of each component. This approach therefore has merit when dealing with homogeneous wastes, and where melt rate restrictions are not limiting. For non-homogeneous wastes the close coupling of the calciner/incinerator functions with the melter is not desirable, since it is necessary to classify the calcined waste to remove large metallic pieces.

The third category of melters is the Joule-heated, ceramic-lined melters. This melter technology is the result of several generations of melter development based originally on commercial, electrically heated melters. Major differences between HLW Melters and commercial melters have been: the use of metal shells to contain glass contact refractories and thermal insulation, development of specialized slurry feeding and glass pouring systems, and the use of nickel based alloys for electrodes carefully matched with glass composition control. The melter is lined with refractory, and the glass is directly heated by conducting electricity through the melt. This system, with slurry feeding, has been selected for all the production melter systems in the U.S., W. Germany and Japan because of high production rates and high glass quality.

The size of these systems is effectively limited only by operating facility constraints (e.g. cell space, crane capacity), since all the structural support is provided by a room temperature metal box which contains the refractory. The Inconel $690^{\mathrm{rm}}$ alloy electrodes only need to be selfsupporting, and high current densities are possible on the faces of the electrodes $\{12\}$. Therefore nominal melt temperatures can be as high as $1150^{\circ} \mathrm{C}$, which is only $200^{\circ} \mathrm{C}$ lower than the alloy melting point $\{11\}$. Glass production rates are proportional to the surface area of the melt, but convection caused by the joule heating is enhanced as the size of the melter is increased, so larger melters have proportionately higher melt rates. There is, however, a limit to this convection increase as the size of the melter increases. Therefore, there is a limit to the melt rate per unit surface area of the melt. For slurry feeding at 40 weight percent solids, 
small laboratory melters operate below 4.5 pounds per hour per square foot, whereas production melters operate at about 8 pounds per hour per square foot. Melt rates can be doubled by dry feeding. The combination of higher temperature and convective mixing makes the glass very homogeneous.

The major difficulty in slurry-fed ceramic-lined designs is the large number of individual refractory bricks, and the supporting shell and other components that are required to be assembled to make this type of melter. This complexity increases the melter construction, installation and disposal costs. In radioactive service only limited repair is possible, so failure of individual components can require removal and disposal of the entire melter.

Melt reaction studies, computerized staged reaction models, organic combustion models and melter redox models are being developed to support the DWPF melter, and have led to the development of a fourth class of melters, known as stirred melters. Evaluation of the melt reaction sequence indicate that the melter operating temperature need not be as high as the nominal $1150^{\circ} \mathrm{C}$ to assure adequate glass durability $\{10\}$. This made possible the consideration of melter designs where Inconel $690^{\mathrm{TM}}$ components carry dynamic loads, which is not possible with the present nominal operating temperature of $1150^{\circ} \mathrm{C}$.

\section{Early Stirred Melter Development}

Several melter design companies were consulted to determine what commercial technology might be applicable. The most promising of these was a proposal by Associated Technical Consultants to develop mechanically stirred melters comparable to those originally investigated by Owens-Illinois Co. $\{7\}$. This approach offered the possibility of combining the size of the continuous pot melters with the high production rates of Slurry Fed Melters: Owens-Illinois demonstrated a compact $2 \mathrm{ft} x$ $2 \mathrm{ft} \times 2 \mathrm{ft}$ melt chamber that produced 24,000 pounds per day of partially melted commercial glass from raw materials. The melter featured a simple geometry, with a simple mechanical drive system, and rapid start, drain and restart capabilities, all of which are desirable properties for radioactive service. 
The existing Owens-Illinois design did not meet the requirements of radioactive waste disposal because it:

1) required natural gas combustion to start,

2) was constructed with electrode and agitator materials chemically incompatible with waste glass feeds,

3 ) produced partially-reacted foam rather than fully-reacted, dense glass,

4) could not guarantee that unreacted batch would not be delivered with the final product,

5) had restricted electrode surface area, and

6) used refractory lining, sharing scale up, glass sealing and disposal concerns with the existing ceramic-lined melters.

A major uncertainty in attempting to apply stirring technology to waste vitrification was the effect of instability of slurry feeding on the melting process. Instabi! ties might cause an uncontrolled amount of entrainment in the off-gas system, result in glass freezing on the agitator, or have uncontrolled flow from the output spout.

It was determined that the necessary characteristics of a agitated wasteglass melter are:

1) adequate durability of glass product,

2) all electrical heating,

3) use of electrode and agitator materials compatible with oxidizing melts,

4) use of alloys with known creep characteristics for predictable melter life,

5) maintenance of temperatures and stresses below creep rupture conditions,

6) elimination of porosity in product glass,

7) stable glass flow with slurry feeding of raw materials,

8) self-sufficient startup power from resistance heaters,

9) vapor space resistance heaters available for melt rate stabilization,

10) vapor space temperature above $600^{\circ} \mathrm{C}$ to combust organics,

11) ability to drain the tank, and

12) predictable melter life greater than 6 months.

To minimize glass sealing concerns, as well as scale up, disposal and repair costs, it is desirable to have all glass contact materials out of one metal alloy rather than a mixture of alloys and refractories. Based on high chromium alloys corrosion studies $\{9\}$, waste melter operating experience, and limited creep rupture and creep strength data $\{11\}$, it 
was specified that all glass contact materials be constructed of Inconel $690^{\mathrm{TM}}$ with a maximum operating temperature of $1075^{\circ} \mathrm{C}$.

For a first attempt at slurry feeding a stirred melter, it was decided that the melter should have about $1 \mathrm{ft}^{2}$ of melt surface. A melter was designed and constructed to these criteria, and tested with simulated HLW slurry $\{1,8\}$. To minimize costs, the melter did not attempt to include mechanical design details required to seal the melter for radioactive service, or to make the melter easily repaired. The design focused on demonstration of the combination of slurry feeding and stirred melting.

The melter had an inside depth of 2.5 feet, and the bottom drain returned up the side of the melter in a teapot spout configuration to maintain a glass depth of 14.5 inches. The spout was insulated with refractories and heated with a gas burner to keep the glass hot enough during pouring. The Inconel $690^{\mathrm{TM}}$ agitator shaft had a 2 inch diameter with 4 flat blades sweeping an 8 incli circle. Heat was supplied to the glass by passing current from the agitator to the Inconel $690^{\mathrm{TM}}$ melter shell. The melter incorporated plenum space heaters for the combustion of organics and for startup heating. A drain hole at the bottom of the melter was plugged with an air cooled steel rod which could be removed to empty the melter. Further details of the design and testing are given in reference 8.

The measured slurry melt rates with the new design were $32 \mathrm{lb} \mathrm{ft}^{-2} \mathrm{~h}^{-1}$ with agitation, and $4.0 \mathrm{lb} \mathrm{ft}^{-2} \mathrm{~h}^{-1}$ without agitation. Maximization of the agitated melt rate was achieved by adjusting the vertical position of the agitator. This change produced an increase in melt rate comparable to the Owens-Illinois stirred melter tests of commercial glass from raw materials $\{10\}$. The demonstrated melt rate was limited by the ability of agitation to disperse the slurry as it was sheared by the underlying foam. Estimated electrode current densities indicated that an additional factor of 2 increase was possible before electrode current limits melt rate. It was therefore concluded that melt rates of about $60 \mathrm{lb} \mathrm{ft}^{-2} \mathrm{~h}^{-1}$ are possible through design optimization.

Since this design uses all metal glass contact materials, only two melter pieces are in contact with the molten glass. Replacement of the tank or agitator is possible, minimizing disposal volumes and costs. This compact design combines the most desirable features of the continuous pot melters and the slurry-fed ceramic-lined melters. 
Due to the need to ensure glass durability and provide complete liberation of bubbles from HLW glass to preclude a pourous glass product, a superheater operated at $1150^{\circ} \mathrm{C}$ (with a glass residence time of at least 4 hours) was felt to be a needed design feature of future HLW stirred melter designs. The superheater, made of Inconel $690^{\mathrm{TM}}$ as well, can be operated at this higher temperature due to the smaller height of the superheater (and the overall shape of the superheater) which minimizes the dynamic loads on the Inconel $690^{\mathrm{TM}}$. This superheater is part of the Full Scale DWPF Stirred Melter design.

Potential benefits of the use of a stirred melter by the DWPF or the HLWDP include lower melter costs; repair of major components (not possible on the present reference melter); shorter down-time for melter changeouts; the usage of a smaller melter of less complex design; easier melter disposal; and higher capacity within the same canyon space.

\section{Status of the TNX Stirred Melter Demonstration}

In December, 1991 the Department of Energy provided $\$ 2,624,000$ for the purpose of purchasing and installing a $3^{\prime} \times 3^{\prime}$ stirred melter at the TNX semiworks facilities. Project $\$ 4845$ was authorized on May 5, 1992. The melter procurement was initiated.

During the summer of 1992 and spring of 1993 several items resulted in changes to the project basis. These included:

- the conceptual design was completed which resulted in scope growth, particularly in the back-up off-gas system,

- project management responsibility for the project was moved from SRTC to the Engineering and Project Division of WSRC at DOE-SR Operations Office instructions. This action resulted in increased design costs, project management fees, and higher reserves,

- changes in the vendor's preliminary design resulted in changes to the scope of the installation, (especially the elertrical requirements) with a corresponding increase in the installation costs, and

- the vendor's quote was $\$ 650,000$ higher than the project basis.

A detailed scope of work was completed which reflected all the known scope changes. A revised project estimate was prepared which 
incorporated all the project management changes. This revised project estimate of $\$ 4,524,000$ was completed on April 14, 1993. The project rebaseline was approved on May 5, 1993.

Meanwhile, in October 1992 Hanford was formally asked to participate in the development of the stirred melter. In February 1993 Hanford authorized a transfer of $\$ 1 \mathrm{M}$ to support the capital project. An additional transfer of up to $\$ 1.3 \mathrm{M}$ in capital funding was authorized in April 1993. The final total funding transferred by Hanford to SRS by both funding authorizations was $\$ 1.65 \mathrm{M}$. 

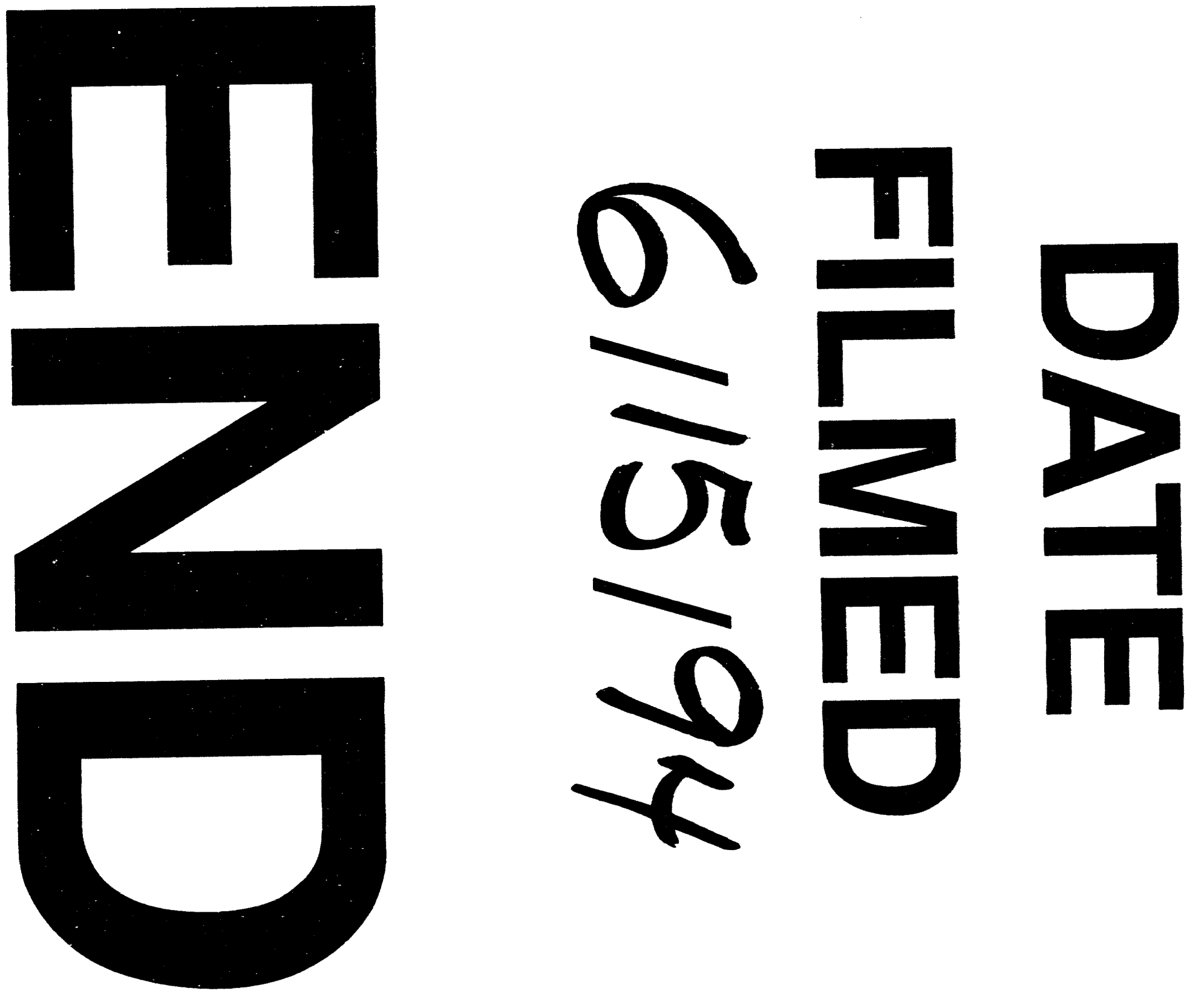


$$
\text { ד. }
$$
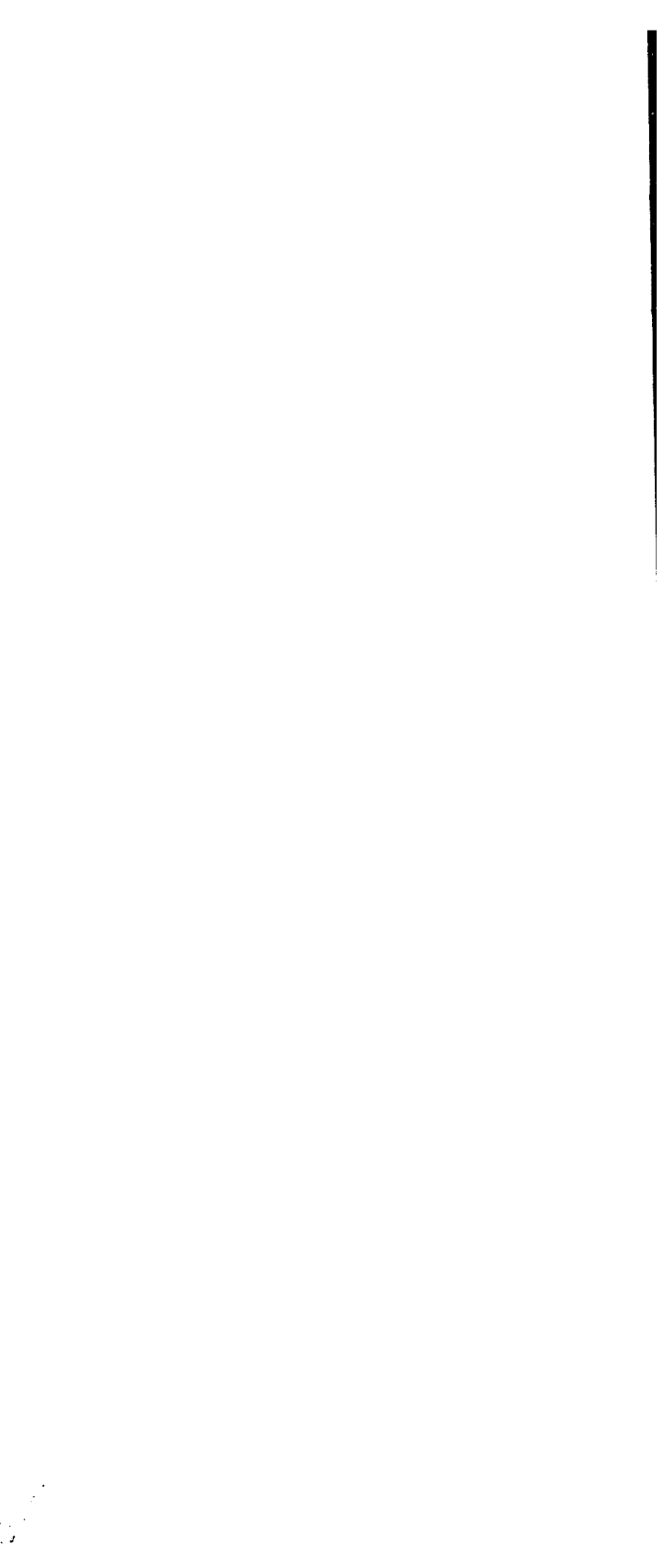